Nutrition and Health (including climate and ecological aspects)

\title{
Vitamin D status and obesity in children from Chile
}

\author{
Francisco Pérez-Bravo $\mathbb{D}^{1,2}$, Lissette Duarte ${ }^{2,3}$, Miguel Arredondo-Olguín ${ }^{1}$, Germán Iñiguez $\mathbb{D}^{4}$ and Oscar Castillo-Valenzuela $\mathbb{D}^{3 凶}$
}

(c) The Author(s) 2021

BACKGROUND: Vitamin D [25(OH)D] is essential for normal bone development and maintenance. Furthermore, its deficiency has been associated with obesity, cardiovascular diseases, insulin resistance, autoimmune diseases, and certain cancers.

OBJECTIVE: To determine the incidence of serum $25(\mathrm{OH}) \mathrm{D}$ deficiency $(<20 \mathrm{ng} / \mathrm{ml})$ among apparently healthy Chilean children

(4-14 years old) from three Chilean geographic areas during May-September 2018.

MATERIALS AND METHODS: Serum 25(OH)D levels were measured by a competitive protein-binding ELISA assay in 1134 children, and correlations between serum 25(OH)D levels, BMI, and geographic area were calculated. Individuals were grouped according to their serum 25-hydroxyvitamin D levels ( $\mathrm{ng} / \mathrm{ml}$ ): severe deficiency: <5; moderate deficiency: 5-10.9; mild deficiency: 11-20.9; insufficiency: 21-29.9 and sufficiency: 30-100.

RESULTS: We found $80.4 \%$ of children had serum $25(\mathrm{OH}) \mathrm{D}$ deficiency, with $1.7 \%$ severe, $24.6 \%$ moderate, and $54.1 \%$ mild. In the three cities, the percentage of serum $25(\mathrm{OH}) \mathrm{D}$ deficit was increased when comparing overweight or obesity with a healthy weight. Additionally, an interaction effect was observed between geographic area, nutritional status, and serum 25(OH)D levels using the factorial ANOVA test $(p=0.038)$. In Antofagasta, there were more overweight children and also a higher percentage of children with VitD deficiency $(<30 \mathrm{ng} / \mathrm{ml})$ compared to Santiago or Concepción.

CONCLUSION: This study revealed a high prevalence of serum 25(OH)D deficiency in children between 4 and 14 years old in Chile $(80.4 \%)$ during May-September 2018. Obese and overweight children had the highest prevalence of serum $25(\mathrm{OH}) \mathrm{D}$ deficiency.

European Journal of Clinical Nutrition (2022) 76:899-901; https://doi.org/10.1038/s41430-021-01043-9

\section{INTRODUCTION}

Vitamin $D(V i t D)$ is essential for developing and maintaining a healthy skeleton, and it has been linked to reduced risk for acute and chronic illnesses [1]. VitD deficiency is associated with obesity, cardiovascular disease, insulin resistance, beta-cell dysfunction, autoimmune diseases, and cancer [2]. Several factors can influence VitD status, including sunlight, diet, and dietary VitD supplements. Besides, lifestyle factors such as for overweight, obesity, and sedentarism also influence VitD status [3].

In Chile, a limited number of studies conducted on healthy children have shown evidence of the impact of nutritional status and sunlight exposure on VitD levels [4].

Childhood obesity is a public health problem in Chile. The latest data published by the OECD show that $74 \%$ of the adult Chilean population are overweight or obese. Furthermore, the FAO report indicates that Chile has one of the highest rates of childhood overweight (9.3\%) in Latin America and the Caribbean [5].

The objective of this study was to analyze serum $25(\mathrm{OH}) \mathrm{D}$ levels in a representative sample of children between 4 and 14 years of age located in the Santiago, Antofagasta, and Concepción.

\section{MATERIALS AND METHODS}

The study was conducted from May to September 2018 with 1134 children aged 4-14 years from different latitudes and UV index (UVI): Antofagasta (north of Chile: $23.65^{\circ} ; 6-7 \mathrm{UVI}$ ), Santiago (central zone: Santiago $33.70^{\circ}$; 4-6 UVI), and Concepción (southern region: Concepción 36.73 ; 3-5 UVI). Study participants were recruited independently of nutritional status according to gender, age group, and socioeconomic status. Children were grouped according to their serum 25(OH)D levels [6].

Anthropometric measurements were made with children in light clothing, weight, and height were measured with a portable stadiometer (SECA 813/213). The nutritional status classification was carried out according to the WHO standards for the age and gender of the children. Children with $\mathrm{BMI} / \mathrm{Age}<+1 \mathrm{DS}$ were classified as healthy weight, those with $\mathrm{BMI} /$ Age between $+1 \mathrm{SD}$ and $+2 \mathrm{SD}$ were classified as overweight, and those with BMI/Age $\geq+2$ SD as obese. Children with chronic diseases, such as diabetes, cancer, or chronic kidney disease, were excluded. Informed consent was obtained from all subjects. The study protocol was reviewed and approved by the Ethics Committee of the University of Chile.

\section{Biochemical measurements}

Serum 25(OH)D was measured in triplicate using an Enzyme-Linked Immunosorbent Assay kit (ELISA, DiaSource, Belgium). Sensitivity of $2 \mathrm{ng} / \mathrm{ml}$ with an intra-assay variation coefficient of $5.1 \%$ and an inter-assay variation coefficient of $5.9 \%$.

\footnotetext{
${ }^{1}$ Institute of Nutrition and Food Technology (INTA), University of Chile, Santiago, Chile. ${ }^{2}$ Nutrigenomics Laboratory, Nutrition Department, Faculty of Medicine, University of Chile, Santiago, Chile. ${ }^{3}$ Nutrition and Dietetics School, Universidad Finis Terrae, Santiago, Chile. ${ }^{4}$ Maternal and Child Research Institute (IDIMI), School of Medicine, University of Chile, Santiago, Chile. ${ }^{凶}$ email: ocastillo@uft.cl
}

Received: 8 March 2021 Revised: 7 October 2021 Accepted: 21 October 2021

Published online: 12 November 2021 


\section{Statistical analysis}

Results are presented as percentages (\%) and means \pm SD. All calculations were performed using the software package SPSS version 15.0.1 (SPSS Inc, Chicago, IL). Shapiro-Wilk normality test was performed to determine the distribution of the variables. Pearson correlation test, factorial ANOVA, oneway ANOVA, and Tukey posthoc analysis were used. In all cases, a value of $p<0.05$ was considered significant.

\section{RESULTS}

Antofagasta's children presented both the highest weight, height, waist circumference, $\mathrm{BMI}$, and height/age ratio relative to the other cities evaluated in this study. We showed a high level of serum $25(\mathrm{OH}) \mathrm{D}$ deficiency in the three cities. The serum $25(\mathrm{OH}) \mathrm{D}$ levels were significantly higher in Antofagasta compared to Concepción (Table 1). In Antofagasta were higher levels of 25 $(\mathrm{OH}) \mathrm{D}$ in boys when compared with girls $(p=0.041)$. In the three cities, the serum $25(\mathrm{OH}) \mathrm{D}$ deficit was increased when comparing overweight or obesity with a healthy weight. An interaction effect was observed between geographic area, nutritional status, and VitD levels using the factorial ANOVA test $(p=0.038)$. In Antofagasta, there were more overweight children and also a higher percentage of children with VitD deficiency $(<30 \mathrm{ng} / \mathrm{ml})$ compared to Santiago or Concepción.

Only $22.4 \%$ in Antofagasta, $20.9 \%$ in Santiago, and $15.5 \%$ in Concepción reached levels of serum $25(\mathrm{OH}) \mathrm{D}>20 \mathrm{ng} / \mathrm{ml}$ (Fig. 1). Finally, regression analysis between the variables gender, age,

\begin{tabular}{|c|c|c|c|c|}
\hline & Antofagasta $(n=354)$ & Santiago $(n=396)$ & Concepción $(n=384)$ & $p$-value \\
\hline Age (years) & $10.1 \pm 2.7^{\mathrm{a}}$ & $9.5 \pm 2.7^{b}$ & $10.0 \pm 2.8^{\mathrm{a}, \mathrm{b}}$ & $<0.01$ \\
\hline Weight (Kg) & 46. $\pm 17.0^{\mathrm{a}}$ & $40.1 \pm 15.7^{b}$ & $42.9 \pm 15.9^{b}$ & $<0.001$ \\
\hline Height (cm) & $143.0 \pm 16.7^{\mathrm{a}}$ & $139.36 \pm 17.5^{b}$ & $142.6 \pm 17.2^{\mathrm{a}, \mathrm{b}}$ & $<0.01$ \\
\hline Waist circumference $(\mathrm{cm})$ & $69.9 \pm 12.0^{a}$ & $64.2 \pm 10.6^{b}$ & $68.2 \pm 11.4^{\mathrm{a}}$ & $<0.001$ \\
\hline BMI $\left(K g / m^{2}\right)$ & $21.7 \pm 4.7^{\mathrm{a}}$ & $19.8 \pm 3.8^{\mathrm{b}}$ & $20.3 \pm 4.1^{b}$ & $<0.001$ \\
\hline zBMI/Age & $1.2 \pm 1.1$ & $1.1 \pm 1.1$ & $1.05 \pm 1.1$ & 0.320 \\
\hline zHeight/Age & $0.50 \pm 1.1^{\mathrm{a}}$ & $0.29 \pm 1.1^{b}$ & $0.11 \pm 0.9^{c}$ & $<0.001$ \\
\hline Dairy consumption (days/wk) & $5.3 \pm 2.1^{\mathrm{a}}$ & $6.1 \pm 1.8^{b}$ & $5.8 \pm 1.9^{b}$ & $<0.001$ \\
\hline Dairy consumption (portions/day) & $1.5 \pm 0.7^{\mathrm{a}}$ & $1.9 \pm 0.8^{b}$ & $1.6 \pm 0.8^{\mathrm{a}}$ & $<0.001$ \\
\hline Fish consumption (days/wk) & $1.0 \pm 0.9$ & $1.1 \pm 1.0$ & $1.1 \pm 1.0$ & $<0.05$ \\
\hline $25(\mathrm{OH}) \mathrm{D}(\mathrm{ng} / \mathrm{ml})^{\mathrm{c}}$ & $15.1 \pm 6.5^{\mathrm{a}}$ & $13.9 \pm 7.1^{\mathrm{a}, \mathrm{b}}$ & $13.8 \pm 5.2^{b}$ & $<0.04$ \\
\hline
\end{tabular}

One-way ANOVA and Tukey post hoc.

a,b Mean values within a row with unlike superscript letters were significantly different.

${ }^{\mathrm{c}}$ Gender differences only in Antofagasta.

\section{$25(\mathrm{OH}) \mathrm{D}$ levels according nutritional status and city}

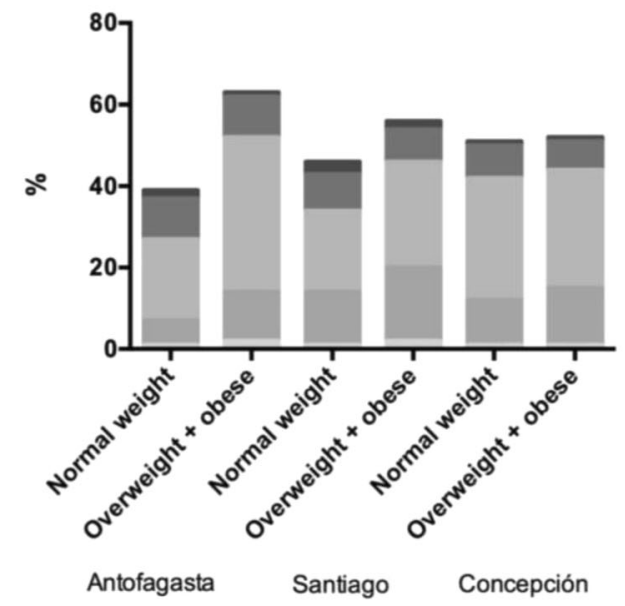

Sufficiency $30-100 \mathrm{ng} / \mathrm{mL}$

Insufficiency $21-29.9 \mathrm{ng} / \mathrm{mL}$

Mild deficiency $11-20.9 \mathrm{ng} / \mathrm{mL}$

Moderate deficiency $5-10.9 \mathrm{ng} / \mathrm{mL}$

Severe deficiency $<5 \mathrm{ng} / \mathrm{mL}$

City/Nutritional status

\begin{tabular}{lcccccc}
\hline & \multicolumn{2}{c}{ Antofagasta } & \multicolumn{2}{c}{ Santiago } & \multicolumn{2}{c}{ Concepción } \\
\hline Vitamin D category & Normal weight & Overweight/Obese & Normal weight & Overweight/Obese & Normal weight & Overweight/Obese \\
\hline Sufficiency $(30-100 \mathrm{ng} / \mathrm{ml})$ & 0.5 & 1.8 & 0.5 & 1.9 & 0.2 & 0.2 \\
\hline Insufficiency $(21-29.9 \mathrm{ng} / \mathrm{ml})$ & 6.4 & 11.9 & 13.3 & 17.5 & 10.9 & 13.8 \\
\hline Mild deficiency $(11-20.9 \mathrm{ng} / \mathrm{ml})$ & 19.6 & 37.4 & 19.9 & 26.0 & 29.9 & 29.4 \\
\hline Moderate deficiency $(5-10.9 \mathrm{ng} / \mathrm{ml})$ & 9.5 & 10.1 & 8.5 & 7.8 & 8.4 & 6.7 \\
\hline Severe deficiency $(<5 \mathrm{ng} / \mathrm{ml})$ & 1.8 & 1.0 & 2.7 & 1.9 & 0.2 & 0.2
\end{tabular}

Fig. 1 Serum 25(OH)D levels by nutritional status in Antofagasta, Santiago, and Concepcion. Factorial ANOVA $\left({ }^{*} p<0.05\right) . p$ City $=0.744, p$ Nutritional status $=0.278, p$ Vitamin D level $=0.008^{*}, p$ Interaction $=0.038^{*}$. According to WHO standards, Nutritional status includes children with $\mathrm{BMI} / \mathrm{Age}<+1 \mathrm{DS}$ classified as normal weight, with BMI/Age between $+1 \mathrm{SD}$ and +2 SD classified as overweight, and those with BMI/ Age $\geq+2$ SD as obese. VitD levels are influenced (jointly, not as independent factors) by the nutritional status of the children and the geographical location where these children live. 
nutritional status, city, and vitamin D status showed that vitamin D is lower at older ages in Santiago and Concepción compared to Antofagasta $(p<0.0001)$.

\section{DISCUSSION}

VitD deficiency was higher in the presence of overweight and obesity. In 2016, Cediel et al. [4] reported deficiencies in 31.9\% of girls and $50.2 \%$ of boys, who associated this deficiency with a higher percentage of adiposity. The prevalence of serum $25(\mathrm{OH}) \mathrm{D}$ deficiency in school children in Colombia reaches $12 \%$ and in Mexico is $24 \%$ of preschoolers and $10 \%$ of school children. In Spain, there are better regional data: $5 \%$ deficiency in Madrid (children between 9 and 13 years old), 45.2\% deficiency in Cádiz (a city with high sun exposure) in children between 10 and 14 years old $[7,8]$. In Navarra, children aged 9.1-13.9 years showed a significantly higher serum $25(\mathrm{OH}) \mathrm{D}$ deficiency in obese compared to normal-weight children (31\% versus $14 \%$ ). Our data show even more dramatic serum $25(\mathrm{OH}) \mathrm{D}$ deficiency than data from Spain or countries with Hispanic heritage [9].

Regardless of geographic location, the magnitude of the deficiency in the analyzed areas has powerfully attracted our attention since they differ in sunlight exposure. During May to September 2018, cloudiness was: Santiago $47-58 \%\left(7-23^{\circ} \mathrm{C}\right)$, Antofagasta $73-84 \% \quad\left(13-24^{\circ} \mathrm{C}\right)$, and Concepción $40-60 \%$ $\left(6-16^{\circ} \mathrm{C}\right)$. Despite this variation, we believe that the high prevalence of overweight/obesity in these regions is the primary condition for VitD sequestration or dilution. In the southern areas of Chile (Punta Arenas), a high prevalence of obesity has been described in school children groups, accompanied by severe VitD deficiencies. Obesity and lack of exposure to sunlight are likely to cause these severe deficiencies [10]. While our study is not without limitations, we believe that sunscreen use, milk consumption, and physical activity are less important than the high prevalence of overweight and obesity in the Chilean population, directly impacting the magnitude of vitamin D deficiency. Serum $25(\mathrm{OH})$ $D$ deficiency could be overestimated, in part because the measurement was carried out in the coldest months (Antofagasta should be considered an exception). In conclusion, our results show a significant deficiency of VitD in Chilean children and adolescents. The decrease in serum VitD is correlated with a higher rate of overweight/obesity, demonstrating that both problems are closely linked to evident long-term adverse effects.

\section{DATA AVAILABILITY}

The datasets used and/or analyzed during the current study are available from the corresponding author on reasonable request.

\section{REFERENCES}

1. Holick MF. The vitamin D deficiency pandemic: approaches for diagnosis, treatment and prevention. Rev Endocr Metab Disord. 2017;18:153-65.

2. Setayesh L, Casazza K, Moradi N, Mehranfar S, Yarizadeh H, Amini A, et al. Association of vitamin D-binding protein and vitamin D3 with insulin and homeostatic model assessment (HOMA-IR) in overweight and obese females. BMC Res Notes. 2021;14:193-9.

3. Pannu PK, Zhao Y, Soares MJ. Reductions in body weight and percent fat mass increase the vitamin $D$ status of obese subjects: a systematic review and metaregression analysis. Nutr Res. 2016;36:201-13.

4. Cediel G, Corvalan C, Aguirre C, de Romana DL, Uauy R. Serum 25-hydroxyvitamin D associated with indicators of body fat and insulin resistance in prepubertal Chilean children. Int J Obes. 2016;40:147-52.

5. OECD. Country statistical profile: Chile. 2020. https://www.oecd-ilibrary.org/sites/ ac9685dd-en/index.html?itemld=/content/component/ac9685dd-en.
6. Holick MF, Binkley NC, Bischoff-Ferrari HA, Gordon CM, Hanley DA, Heaney RP, et al. Evaluation, treatment, and prevention of vitamin D deficiency: an Endocrine Society clinical practice guideline. J Clin Endocrinol Metab. 2011;96:1911-30.

7. Brito ACH, Olivares M, Mujica F, Cediel G, López de Romaña D. Less than adequate vitamin $D$ status and intake in Latin America and the Caribbean: a problem of unknown magnitude. Food Nutr Bull. 2013;34:52-64.

8. Braegger C, Campoy C, Colomb V, Decsi T, Domellof M, Fewtrell M, et al. Vitamin $\mathrm{D}$ in the healthy European paediatric population. J Pediatr Gastroenterol Nutr. 2013;56:692-701.

9. Melamed ML, Kumar J. Low levels of 25 -hydroxyvitamin $D$ in the pediatric populations: prevalence and clinical outcomes. Pediatr Health. 2010;4:89-97.

10. Brinkmann K, Le Roy C, Iñiguez G, Borzutzky A. Severe vitamin D deficiency in children from Punta Arenas, Chile: influence of nutritional status on the response to supplementation. Rev Chil Pediatr. 2015;86:182-8.

\section{ACKNOWLEDGEMENTS}

We thank all participating schools for their cooperation. This project was supported by unrestricted Grant from Nestlé. The resources were granted through Chile's Donations Law, where there is no involvement in the research between the donor and the institution.

\section{AUTHOR CONTRIBUTIONS}

Conceptualization: Francisco Pérez Bravo and Oscar Castillo Valenzuela; Formal analysis: Francisco Pérez Bravo, Lissette Duarte, Miguel Arredondo-Olguín, Germán Iñiguez, Oscar Castillo Valenzuela; Investigation: Francisco Pérez Bravo and Oscar Castillo Valenzuela; Writing-original draft, Francisco Pérez Bravo and Oscar Castillo Valenzuela; Writing—review and editing, Lissette Duarte, Miguel Arredondo-Olguín, Germán Iñiguez.

\section{COMPETING INTERESTS}

The authors declare no competing interests.

\section{ETHICS APPROVAL AND CONSENT TO PARTICIPATE}

The study was approved by the ethics committee of the Institute of Nutrition and Food Technology of the University of Chile. Parents and guardians signed informed consent, and schoolchildren gave their consent for nutritional and biochemical evaluations.

\section{ADDITIONAL INFORMATION}

Correspondence and requests for materials should be addressed to Oscar CastilloValenzuela.

Reprints and permission information is available at http://www.nature.com/ reprints

Publisher's note Springer Nature remains neutral with regard to jurisdictional claims in published maps and institutional affiliations.

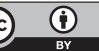

Open Access This article is licensed under a Creative Commons Attribution 4.0 International License, which permits use, sharing, adaptation, distribution and reproduction in any medium or format, as long as you give appropriate credit to the original author(s) and the source, provide a link to the Creative Commons license, and indicate if changes were made. The images or other third party material in this article are included in the article's Creative Commons license, unless indicated otherwise in a credit line to the material. If material is not included in the article's Creative Commons license and your intended use is not permitted by statutory regulation or exceeds the permitted use, you will need to obtain permission directly from the copyright holder. To view a copy of this license, visit http://creativecommons. org/licenses/by/4.0/.

(c) The Author(s) 2021 